\title{
Egyed Ákos
}

\section{Emlékbeszéd ${ }^{1}$}

Tisztelt emlékező, emlékállító gyülekezet!

Kedves gyerőmonostoriak, kalotaszegiek, mindnyájan!

Úgy tudjuk, bizonyosan jól tudjuk, hogy itt Magyargyerőmonostoron annak a háznak a helyén állunk, ahol régen, ezelőtt mintegy 200 évvel Debreczeni János fazekasmester hajléka volt.

Vajon milyen lehetett a ház, amelyben Debreczeni Jánosné Lörincz Erzsébet 1802. január 25-én életet adott annak a kisfiúnak, aki a keresztségben a Márton nevet kapta. Bizony annak a háznak az alakját ma aligha tudná valaki pontosan elképzelni vagy leírni. Mégis aligha tévedünk, amikor azt mondjuk, bizonyosan egyszerü, kicsi, alacsony, szegényes épület lehetett az a szülői ház, amelyben Debreczeni Márton az annyira meghatározó jelentőségü gyermekéveket töltötte, olyan volt, mint akkortájt az egyszerü kalotaszegi emberek hajléka általában.

De ki merészelne véleményt mondani valamely család életéről a lakóház külseje alapján?

Hiszen nagy palotákban is lehetett lelki és szellemi szegénység, és fordítva: kunyhókban is lehetett és volt boldog, gazdag, szép otthonos családi élet. Úgy gondoljuk, ilyen lehetett a Debreczeni János és Lőrincz Erzsébet kis házának családi élete. Erre enged következtetni a benne nevelkedett fiú, Debreczeni Márton egész élete. Ö a szegényes otthontól gazdag örökséget, kiváló indíttatást kapott az élethez. Ezt vitte tovább, fejlesztette szépen nemes lelkisége s kiemelkedő talentuma által egészen a magas fokú társadalmi elismertségig.

Debreczeni Márton életéről, életpályájáról többen írtak, s még többen vallottak életében és halála után. És mindenki, kivétel nélkül a legnagyobb elismeréssel, mondhatni őszinte csodálattal szólt róla. Mi, mai emlékezők sem tehetünk másképpen. Az elismerés, a csodálat szólhat arról a tanulni vágyó „kis köpcös, kékszemü, bátortalan, fehér condrájú" ifjúról, akit a kolozsvári Református Főtanodában így ismertek meg.

Szólhat és szól az ifjúnak a tudományok terén elért kiváló eredményeiről, arról az útról, amely a gyerőmonostori elemi iskolából a selmecbányai, Európa-szerte elismert bányászati akadémiáig vezetett; arról, hogy Debreczeni Márton nem ásta el az Istentől kapott és szüleitől örökölt talentumát, hanem gazdagon gyümölcsöztette: a kis falu fiából, az egyszerủ család sarjából elismert bányatanácsos és feltaláló lett; szólhat és szóljon is arról ez a pályaív Magyargyerőmonostorról a magyar fövárosig, Pest-Budáig, Kossuth első felelős magyar pénzügyminiszter minisztériumába vezetett, szóljon arról, hogy Kossuth Lajos sietett rábízni Erdély pénzügyeinek rendbetételét. Nem feledkezhet meg az emlékezés arról sem, hogy a számokkal és ásványokkal foglalatoskodó tudósunkban költői lélek lakozott, aki az ősökről, a magyarok régi dicsőségéről írt megkapó szép versezetet, és aki szívvel és lélekkel,

\footnotetext{
${ }^{1}$ A Magyargyerỏmonostoron 2002. szeptember 7-én tartott megemlékezésen elhangzott beszéd.
} 
teljes tudásával szolgálta az 1848-as forradalom és szabadságharc idején a magyarok ügyét, amelyet meggyôzződéssel igazságosnak tartott.

Emlékeztetünk és emlékezünk a nagy tudós leírhatatlan szerénységéröl, egyszerủ életviteléről, jó humoráról, eredetiségéröl: „O eredeti fö, valódi lángész volt, ki magából fejlődött ki, és kinek csak meg kellett mutatni az utat, hogy maga menjen rajta, tovább, mint az útmutató" - írta róla egyik kiváló ismerôje.

De csodálkozásunk közben nehogy megfeledkezzünk azokról, akik őt pártfogolták, támogatták, ezek közt is elöször arról, aki tehetségét felfedezte s majdhogy kézen fogva vezette tovább tanulni Erdély fövárosába, Kolozsvárra, aztán arról, aki barátságába fogadta, maga mellé vette az erdélyi kincstartóságban, közismertté tette az irodalomban, vagyis gróf Mikó Imrérỏl, akit Erdély Széchenyijeként szoktuk emlegetni.

Az Erdélyi Múzeum-Egyesület, Erdély legrégebbi, ma is múködő magyar tudományos intézménye Debrcczeni Mártont saját előfutárai között tartja számon, még akkor is, ha korábban eltávozott az élök sorából, még mielőtt Egyesületünk megalakult. Nemrég, a kolozsvári megemlékezésünk alkalmából, Egyesületünk akkori elnöke, Benkő Samu, a Házsongárdi Pantheonban nem fukarkodott elismerö szavakkal méltatni Debreczeni Márton hozzájárulását az erdélyi magyar tudományosság, a magyar tudományos nyelv fejlesztéséhez.

Ezeket mind magaménak is vallva, mint az Erdélyi Múzeum-Egyesület jelenlegi elnöke megigérem: Debreczeni Mártonnak, Magyargyerömonostor nagy szülöttének, az erdélyi tudományosság jelentős alakjának, a szépen verselö romantikus költőnek alakját nem engedjük feledésbe merülni, s nemes szellemét ápolni fogjuk. 